\title{
La arbitrabilidad del incumplimiento del Estado a la cláusula de estabilidad jurídica en el contrato de gestión delegada: Análisis del alcance del artículo 20.2 de la Ley Orgánica de Incentivos para Asociaciones Público-Privadas y la Inversión Extranjera*
}

\author{
María Bernarda Carpio Frixone $e^{* *}$ \\ Recibido/Received: 25/06/2018 \\ Aceptado/Accepted: 20/07/2018
}

SuMARIO: 1. Introducción. 2. La cláusula de estabilidad en el Derecho de Inversiones y su regulación en la legislación ecuatoriana. 2.1 Acercamiento a la cláusula de estabilidad jurídica en el Derecho de Inversiones. 2.2 La cláusula de estabilidad no compromete la soberanía estatal. 2.3 La cláusula de estabilidad jurídica y su tratamiento en Ecuador. 3. Naturaleza de los compromisos asumidos por el Estado a través de la suscripción de una cláusula de estabilidad jurídica y los efectos de su incumplimiento. 3.1 La cláusula de estabilidad como una obligación de no hacer del Estado. 3.2 El incumplimiento del Estado a la cláusula de estabilidad se da me-

* Este artículo es una adaptación del Trabajo de Titulación presentado para la obtención del título de Abogada, el cual se encuentra disponible en $<$ https://goo.gl/F2oDuQ $>$.

** Abogada summa cum laude por la Universidad San Francisco de Quito con subespecialización en Manejo de Conflictos, Negociación, Mediación y Arbitraje. Correo electrónico: mbernarda.carpio@gmail.com

M.B. CARPIO FriXone, "La arbitrabilidad del incumplimiento del Estado a la cláusula de estabilidad jurídica en el contrato de gestión delegada: Análisis del artículo 20.2 de la Ley Orgánica de Incentivos para Asociaciones Público-Privadas y la Inversión Extranjera", Revista Ecuatoriana de Arbitraje, No. 9, 2017. 
diante la aplicación de la ley, no por su mera promulgación. 3.3 El incumplimiento del Estado se materializa a través de actos administrativos. 3.4 El régimen indemnizatorio ante el incumplimiento del Estado a la cláusula de estabilidad. 3.4.1 El régimen indemnizatorio ante el incumplimiento de las obligaciones de no hacer. 3.4.2 ¿Cabe la destrucción del hecho prohibido ante el incumplimiento a la cláusula de estabilidad? 3.4.3 En caso de no mediar destrucción del hecho prohibido, la Entidad Delegante debe indemnizar al inversionista. 4. La arbitrabilidad del incumplimiento del Estado a la cláusula de estabilidad. 4.1 El arbitraje al amparo de la Ley APP. 4.2 El incumplimiento del Estado a la cláusula de estabilidad: ¿un caso de arbitrabilidad de actos administrativos? 4.3 El incumplimiento a la cláusula de estabilidad es arbitrable. 4.3.1 El incumplimiento a la cláusula de estabilidad no deriva de la potestad legislativa ni regulatoria del Estado. 4.3.2 El incumplimiento del Estado a la Cláusula de Estabilidad es un asunto netamente contractual, razón por la cual su arbitrabilidad es indiscutible. 5. Conclusiones.

Palabras clave: arbitrabilidad, alianza público-privada, cláusula de estabilidad.

KEYWORDS: arbitrability, public-private partnership agreement, stabilization clause.

RESUMEN: La inversión extranjera se presenta como una alternativa idónea para potenciar la economía del país. En diciembre de 2015 se promulgó la Ley Orgánica de Incentivos para Asociaciones Público-Privadas y la Inversión Extranjera (en adelante, Ley APP). Dentro de los incentivos reconocidos en esta ley se encuentran la posibilidad de incluir en los contratos de gestión delegada (i) una cláusula de estabilidad y (ii) una cláusula arbitral. A través de la primera se asegura al inversionista certeza sobre el marco jurídico que regulará su inversión; por su parte, la segunda garantiza la posibilidad de acudir a una sede imparcial a fin de resolver cualquier eventual disputa entre el Estado y el inversionista. El artículo 20.2 de la Ley APP excluye la posibilidad de someter a arbitraje los actos que deriven directamente de la potestad legis- 
lativa o regulatoria del Estado. Ante esto surge la siguiente interrogante ¿es arbitrable el incumplimiento del Estado a la cláusula de estabilidad? El propósito de este artículo es analizar el alcance del referido artículo a fin de concluir que el incumplimiento del Estado a la cláusula de estabilidad es arbitrable.

Abstract: Foreign investment is an ideal alternative to bust the country's economy. Thus, in December 2015, the Organic Law of Incentives for Public-Private Partnerships and Foreign Investment (onwards, PPP Act) was enact. Among the incentives recognized in this statute are the possibility of including in the public-private partnership agreement (i) a stabilization clause and (ii) an arbitration clause. The stabilization clause gives certainty about the legal framework that will govern the investment and the arbitration clause guarantees the possibility of accessing an impartial jurisdiction for resolving any possible dispute between the State and the investor. Article 20 of the PPP Act excludes the possibility of submitting to arbitration acts that derive directly from the legislative or regulatory power of the State. This article arises the following question: can breach of the stability clause be solved in arbitration? The purpose of this article is to clarify the scope of article 20.2 of the PPP Act in order to determine that breach of the stabilization clause can be solved in arbitration.

\section{INTRODUCCIÓN}

Uno de los incentivos que contempla la Ley APP es la incorporación de una cláusula de estabilidad jurídica en el contrato de gestión delegada. En virtud a dicha cláusula el Estado se compromete a congelar la normativa sectorial específica, que haya sido declarada como relevante en el contrato de gestión delegada, de suerte que, ninguna modificación posterior pueda ser aplicada al inversionista. Es por ello que la inclusión de esta cláusula consti- 
tuye un mecanismo de protección al otorgar certeza sobre el marco jurídico que regirá la inversión.

Por otro lado, en su artículo 20.2, la Ley APP también reconoce la posibilidad de pactar una cláusula arbitral a fin de someter a arbitraje la resolución de controversias que surjan respecto al contrato. Esta posibilidad es otra de las garantías que tiene el inversionista. Debe tomarse en cuenta que la entidad delegante es parte del Estado, por lo que acudir a una sede fuera de la jurisdicción estatal asegura la imparcialidad en la resolución del conflicto y, por tanto, configura una protección adicional para el inversionista.

Si bien, por un lado, la Ley APP reconoce la posibilidad de suscribir una cláusula de estabilidad y un convenio arbitral; por otro, también prescribe que "[no] se someterán a arbitraje los asuntos tributarios, así como ningún otro acto que se derive directamente de la potestad legislativa y regulatoria del Estado ecuatoriano" ${ }^{\prime 1}$. Al excluir la posibilidad de arbitrar cualquier acto que derive de estas potestades, podría ponerse en tela de duda la arbitrabilidad de un eventual incumplimiento del Estado a la cláusula de estabilidad.

El alcance de esta norma puede ser malinterpretado, pues podría creerse que la aplicación de una nueva ley a un inversionista extranjero, que se encuentra amparado por la cláusula de estabilidad, es un acto que deriva de la potestad regulatoria o legislativa del Estado y como tal no podría ser arbitrable. De adoptarse esta postura, se estaría imposibilitando al inversionista reclamar en arbitraje el incumplimiento de una de sus principales garantías.

La conclusión de este artículo es que el incumplimiento del Estado a la cláusula de estabilidad es arbitrable, pues escapa de la prohibición del artículo 20.2 de la Ley APP. Para sostener aquello se tratará en primer lugar la naturaleza de la cláusula de estabilidad jurídica y su tratamiento en la legislación ecuatoriana; en

1. Ley Orgánica de Incentivos para Asociaciones Público-Privadas y la Inversión Extranjera (Ley APP), Art. 20, RO Sup. No. 652, 18/12/2015. 
segundo lugar, se estudiarán los efectos del incumplimiento a la cláusula de estabilidad; para, finalmente, analizar su arbitrabilidad.

\section{La Cláusula de estabilidad en el Derecho de IN- VERSIONES Y SU REGULACIÓN EN LA LEGISLACIÓN ECUATORIANA}

A fin de comprender el compromiso que asume el Estado al suscribir una cláusula de estabilidad jurídica, corresponde en primer lugar analizar su naturaleza en el Derecho de Inversiones [2.1], a fin de aclarar que la celebración de esta cláusula no compromete la soberanía estatal [2.2]. Finalmente se estudiará su tratamiento en el ordenamiento jurídico ecuatoriano [2.3].

\subsection{Acercamiento a la cláusula de estabilidad jurídica en el Derecho de Inversiones}

Dentro del Derecho de Inversiones, existen algunas herramientas para proporcionar seguridad al inversionista ${ }^{2}$, una de ellas es la cláusula de estabilidad jurídica (conocida también como cláusula de congelamiento) ${ }^{3}$. Esta cláusula es un mecanismo legal

2. Otro tipo de cláusulas de estabilización son las cláusulas de equilibrio económico y las cláusulas híbridas. Para mayor información al respecto, véase, A. AL FARUQUE, "Validity and Efficacy of Stabilisation Clauses. Legal Protection v. Functional Value", Journal of Internacional Arbitration, Vol. 23 (4), 2006, p. 319; E. PAASIVIRTA, "Internationalization and Stabilization of Contracts versus State Sovereingnty”, British Yearbook of International Law, 1989, p. 323; J. CASTAÑO y P. GALEANO, Los contratos de estabilidad jurídica en Colombia, Eafit, 2011, p. 71; S. FrANK, "Stabilisation Clauses and Foreign Direct Investment: Presumptions versus Realities", The Journal of World Investment \& Trade, No. 16, 2015, pp. 89-91; K. GeHNE y R. BRILlo, Stabilization Clauses in International Investment Law: Beyond Balancing and Fair and Equitable Treatment, Transnational Economic Law Research Center, 2017, pp. 6-9; y, J. SINGH, "Stabilization Clauses in Investment Contracts in Developing Countries", <http://ssrn.com/abstract=2658185>; L. CотULA, "Regulatory takings, stabilization clauses and sustainable development"; OECD Global Forum on International Investment VII, 2008, p. 5, $<$ goo.gl/pCvmyr $>$.

3. Véase, G. Delaume, “Transnational Contracts: Applicable Law and Settlement of Disputes”, Law and Practice No. 8, 1983, p. 39; L. GRANATO y C. NAhUEl Oddone, "La protección internacional del inversor extranjero a través de los acuerdos bilaterales de inversión”, Revista de la Facultad de Ciencias Económicas y Administrativas Universidad de Nariño, Vol. VIII (2), 2007, p. 59; P. DUMBERRY, International Investment Contracts, en T. GAZZINI y E. DE BRABANDERE (Ed.), International Investment Law. The Sources of Rights and Obligations, Leiden, 2012, p. 221; D.C. BERNAL, El Derecho Interna- 
que brinda certeza al inversionista sobre las reglas del juego ${ }^{4}$. En este sentido:

Las cláusulas de estabilidad en estricto sensu tienen concordancia con el principio de no retroactividad de la ley. Mediante estas cláusulas la ley que está en vigor en el Estado receptor, al momento de la ratificación de la concesión, es la ley que será aplicable para suplir los términos del contrato, a pesar de posteriores promulgaciones del gobierno. En suma, el propósito de éstas es precluir el acuerdo de la aplicación de cualquier subsecuente actuación legislativa (estatutaria) o administrativa (regulatoria) por el gobierno [...] que modifique la situación legal del inversionista. Es precisamente por esta razón que las cláusulas de estabilidad o estabilización jurídica son uno de los tipos contractuales e incentivos fiscales más utilizados por los países en desarrollo para la atracción de inversión extranjera directa a sus territorios ${ }^{5}$.

En efecto, el objetivo primordial de estas cláusulas es "asegurar el acuerdo frente a futuras acciones del gobierno o cambios en la ley"6. Estas cláusulas pueden ser totales o parciales. Las primeras garantizan el congelamiento de todas las leyes que podrían afectar al inversionista, mientras que las segundas únicamente brindan estabilidad sobre normativa específica ${ }^{7}$.

Si bien las cláusulas de estabilidad "pretenden congelar las leyes existentes desde el momento del perfeccionamiento del contrato hasta el momento de su terminación"; ; de suerte que "ningún cambio en la legislación del Estado receptor que afecte al inversionista podrá aplicársele" ${ }^{\prime \prime}$; su suscripción no implica una

cional de Inversión, Las Cláusulas de Estabilidad: ¿un caso de protección internacional prima facie?, Editorial Académica Española, 2013, p. 137; y C. RodríguEZ-Yong y K. MARTínEZ-MuÑoz, “The Andean approach to stabilisation clauses", International Journal of Private Law, Vol. 6 (1), 2013, pp. 6869.

4. D.C. Bernal Pérez, N. 3, p. 150.

5. Ídem, p. 153.

6. C. CURTIS, "The Legal Security of Economic Development Agreements", Harvard International Law Journal No. 29, 1988, p. 246.

7. Véase, D. C. MARÍN Vergara, Contratos de estabilidad jurídica para la promoción de las inversiones: la experiencia colombiana, Tesis de grado. Universidad de los Andes, Bogotá, 2013, p. 5.

8. J. Castaño y P. Galeano, N. 2, p. 72.

9. R. Dolzer y C. Schreuer, Principles of International Investment Law, Oxford: Oxford University Press, 2008, p. 75. 
renuncia por parte del Estado a la potestad de emitir normativa futura.

Al contrario, "esta cláusula simplemente impide la aplicación de la nueva legislación al acuerdo de inversión"10. En consecuencia, el Estado mantiene su aptitud para modificar y actualizar su ordenamiento jurídico cuantas veces lo desee, pero estas alteraciones no son aplicables al inversionista vis-a-vis con el Estado. Ello debido a que la cláusula de estabilidad no compromete la soberanía estatal.

\subsection{La cláusula de estabilidad no compromete la soberanía estatal}

Dentro del Derecho de Inversiones algunos doctrinarios han cuestionado la validez de la cláusula de estabilidad ${ }^{11}$. Esta crítica se debe a que "en su forma más pura [...] las cláusulas de congelamiento prohíben contractualmente al Estado la promulgación de legislación incompatible con los términos del acuerdo"12. Esta concepción ha puesto en tela de duda a las cláusulas de estabilidad, pues "[algunos escritores] [s]ostienen que la cláusula impone restricciones importantes al derecho soberano de un Estado a ejercer su prerrogativa legislativa dentro de su propio territorio $[\ldots]^{\prime \prime 13}$.

DOLZER y SCHREUER explican que existen dos perspectivas sobre el alcance de la cláusula de estabilidad. La primera -aquella que sostienen quienes critican la validez de este tipo de cláusulas-radica en que "cualquier cambio en la legislación aplicable al contrato [...] contraviene la cláusula de estabilidad"14. En cambio, la segunda "apunta a proteger la soberanía del Estado receptor y sostiene que todo cambio en la legislación es permitido, pero que

\footnotetext{
10. Traducción libre. M. SAR, Stabilization Clauses in Investment Contracts, p.12, <goo.gl/oyXc9R>.

11. Véase, A. Al Faruque, N. 2, pp. 323-325; M. Sornarajah, The International Law on Foreign Investment, Cambridge Press, 2010, pp. 282-284; C. RodríGuez-Yong y K. Martínez-MuÑoz, N. 3, pp. 70-71 y, K. Gehne y R. Brillo, N. 2, pp. 3-5.

12. Traducción libre. M. SAR, N. 10, p. 12.

13. Traducción libre. P. Dumberry, N. 3, p. 221.

14. Traducción libre. R. Dolzer y C. SChreuer, N. 9, p. 75.
} 
conlleva el deber de compensar a la compañía extranjera que está protegida por la cláusula de estabilidad"15.

Frente a la existencia de estas dos posturas, es importante notar que al inversionista no le interesa que el Estado se abstenga de modificar su legislación indistintamente, sino que pretende no verse afectado por dicha modificación. Por tanto, lo que realmente busca el inversionista es que la legislación sea congelada para él, no en general. De este modo es posible desvirtuar la primera postura, ya que el verdadero objetivo de una cláusula de estabilidad no es impedir al Estado que legisle, sino evitar que los efectos de las nuevas normas afecten una inversión en concreto.

Al respecto, el tribunal arbitral del caso AGIP c. República Popular del Congo reconoció la validez de las cláusulas de estabilidad al señalar que "[e]stas cláusulas de estabilización, aceptadas libremente por el Gobierno, no afectan al principio de soberanía sobre sus facultades legislativas y reglamentarias, ya que las conserva frente a los nacionales y extranjeros con los que no ha asumido tales obligaciones"16. De igual modo se pronunció el tribunal arbitral en el caso Texaco Overseas Petroleum Company c. República de Libia al sostener que "Libia conserva todas sus facultades para regular el campo de las actividades petroleras respecto de nacionales y extranjeros con los que no asumió tal compromiso [contenido en cláusula de estabilidad]"17. Por lo tanto, la cláusula de estabilidad no contraviene la soberanía estatal. Precisamente, al pactar una cláusula de estabilidad jurídica,

[...] el Estado anfitrión promete que la legislación posterior no se aplicará a la relación entre las partes en el acuerdo. Por lo tanto, este tipo de cláusula no equivale a una renuncia a la soberanía estatal para legislar; significa más bien que la legislación posterior no se aplique al contrato (énfasis añadido) ${ }^{18}$.

15. Ibídem.

16. Traducción libre. AGIP c. República Popular del Congo, Laudo final, 30/11/1979, pp. 735-736. En el caso LETCO c. Liberia el tribunal arbitral también reconoció la validez de estas cláusulas al sostener que "la cláusula de estabilidad debe ser respetada [...]. De lo contrario, el Estado contratante podría fácilmente evadir sus obligaciones contractuales".

17. Traducción libre. Texaco Overseas Petroleum Company c. República de Libia (en adelante, TOPCO c. Libia). Laudo final, 19/01/1977, párr. 71.

18. Traducción libre. A. Al Faruque, N. 2, p. 329. 
A su vez, otro de los argumentos que permite otorgarle validez a la cláusula de estabilidad gira en torno a la posibilidad que tiene el Estado, en ejercicio de su soberanía, de autolimitarse. Así, DUMBERRY explica que "[...] [n]ada impide que un Estado acuerde restringir su propia autoridad y tal concesión es, de hecho, un acto de soberanía en sí mismo"119. Si la legislación del Estado receptor de la inversión permite la incorporación de tales cláusulas, no hay razón para cuestionar su validez. Al contrario, su suscripción es como tal un acto soberano ${ }^{20}$. Precisamente por estos motivos AL FARRUQUE denomina a estas cláusulas como:

[...] una limitación autoimpuesta, pero temporal, a la soberanía de los Estados receptores [que no puede ser] interpretada como un bloque absoluto sobre el poder legislativo del Estado [porque] simplemente [significa] que cualquier legislación promulgada posteriormente, que pueda tener un impacto especialmente adverso sobre el régimen del contrato, no le será aplicable (énfasis añadido) ${ }^{21}$.

En este sentido, en el caso TOPCO c. Libia, el tribunal arbitral estimó que la cláusula de estabilidad no afectó la soberanía legislativa de Libia. Al contrario, señaló que Libia ejerció dicha soberanía "aceptando la inclusión de cláusulas de estabilización pactadas con una parte privada extranjera" ${ }^{\prime 22}$. De este modo el tribunal consideró que "el Estado no puede invocar su soberanía para desconocer compromisos que asumió libremente a través del ejercicio de esa misma soberanía" ${ }^{23}$. Así, sobre la base de ello, afirmó que el hecho que el Estado deba abstenerse de aplicar al inversionista una determinada ley no se debe a que la soberanía de Libia haya sido reducida, sino que simplemente se debe al hecho que Libia, a través del ejercicio de su soberanía, asumió este compromiso ${ }^{24}$. El mismo criterio llevó al tribunal arbitral del

19. Ibídem.

20. H. Smith Freehills, Stabilisation clauses- issues and trends, <goo.gl/dhWrdk> (20/03/2017); y C. RoDRÍGUEZ-Yong y K. MARTíneZ-MuÑoz, N. 3, p. 70.

21. Traducción libre. A. Al FaruQue, N. 2, pp. 324-325.

22. Traducción libre. TOPCO c. Libia, N. 17.

23. Ídem, párr. 68 .

24. Ídem, párr. 71. 
caso Arabia Saudita c. Arabian American Oil Co. a reconocer la validez de la cláusula de estabilidad ${ }^{25}$.

A pesar de ello, es importante reconocer que "el ejercicio por parte del Estado de su potestad soberana en pos del interés público no puede negarse en el contexto de las clásicas cláusulas de estabilización" ${ }^{\prime 26}$. Ello quiere decir que independientemente de si se pactó una cláusula de estabilidad, el Estado conserva su potestad para aplicar la norma modificada, inclusive, al inversionista protegido por la inversión. A esta posibilidad se refiere precisamente la segunda postura mencionada por DOLZER y SCHREUER ${ }^{27}$.

Si ello ocurre, el Estado deberá responder por los perjuicios ocasionados. Así, en el caso LIAMO c. República de Libia el tribunal arbitral sostuvo que, debido al principio de soberanía estatal, resulta imposible impedir a través de cláusulas de congelamiento que un Estado cambie su ley. Sin embargo, reconoció que al incluir en un contrato una cláusula de estabilidad, el Estado es responsable ante su incumplimiento, por lo que el inversionista puede reclamar de indemnización correspondiente ${ }^{28}$. Así, "las cláusulas de estabilidad, al no privar al Estado del ejercicio de su inalienable facultad de legislar en razón del interés público, la principal consecuencia jurídica del incumplimiento a la cláusula de estabilidad es la obligación de pagar una compensación (énfasis añadido)" ${ }^{\prime 2}$.

Al no ser posible limitar la soberanía estatal mediante la celebración de una cláusula de estabilidad, la garantía que obtiene el inversionista a través de su suscripción es "recibir una indem-

25. En este caso el tribunal señaló que "En razón de su propia soberanía en su territorio nacional, el Estado posee los poderes legales para otorgar derechos [al inversionista] [...]. Nada puede impedir que un Estado, en el ejercicio de su soberanía, se vincule irrevocablemente por las disposiciones de una concesión y otorgue al concesionario derechos irrevocables. Tales derechos tienen el carácter de derechos adquiridos". Arabia Saudita c. Arabian American Oil Co. Laudo final, 23/08/1958, párr. 168.

26. A. F. M. MANiRUZZAMAN, "The pursuit of stability in international energy investment contracts: A critical appraisal of the emerging trends", Journal of World Energy Law \& Business, Vol.1 (2), 2008, p. 138.

27. R. Dolzer y C. Schreuer, N. 9, p. 75.

28. Libyan American Oil Company (LIAMCO) c. República de Libia, Laudo final, 12 de abril de 1977, pp. 121-122 y 167-168.

29. Traducción libre. A. Al FaruQue, N. 2, p. 330. 
nización mayor, por el daño ocasionado, a la que le correspondería en aquellos casos en los que no exista tal cláusula"30. Así, la Corte Constitucional de Colombia, al referirse al alcance de las cláusulas de estabilidad, fue enfática al sostener que a pesar de haberse pactado una cláusula de estabilidad, "los órganos del Estado conservan plenamente sus competencias normativas, incluso sobre las normas identificadas como determinantes de la inversión, sin perjuicio de las acciones judiciales a que tengan derecho los inversionistas" 31 .

En consecuencia, al suscribir una cláusula de estabilidad, el Estado no renuncia a su potestad soberana de legislar, sino que se abstiene de aplicar las nuevas normas al inversor. Dicha aclaración es de suma importancia, pues únicamente sobre la base de ella será posible determinar cómo se configura el incumplimiento del Estado a la cláusula de estabilidad (sección 3.2).

\subsection{La cláusula de estabilidad jurídica y su tratamiento en Ecuador}

Una vez expuesto el concepto y alcance de la cláusula de estabilidad jurídica, corresponde analizar cuál es su tratamiento en el ordenamiento jurídico ecuatoriano. En Ecuador las cláusulas de estabilidad jurídica son plenamente válidas. La legislación ecuatoriana las reconoce como un instrumento idóneo y legítimo para incentivar la inversión extranjera. Estas cláusulas son reco-

30. A. F. M. Maniruzzaman, N. 26, p. 126.

31. Corte Constitucional de la República de Colombia, Sentencia C-320, Gaceta de la Corte Constitucional, 24/04/2006. En esta línea argumentativa, la Corte Constitucional colombiana, en el mismo precedente, sostuvo que "[...] la Ley 963 de 2005 no le está impidiendo al Congreso de la República ejercer su competencia en el futuro para reformar las leyes [...]; lo que sucede es que, dichas modificaciones, llegado el caso, pueden dar origen a controversias con los inversionistas, para cuya solución las partes pueden incluir una cláusula compromisoria mediante la cual se prevé la conformación de un tribunal de arbitramento. En otras palabras, no se está garantizando una inmutabilidad del ordenamiento jurídico colombiano, por cuanto, de llegar a entendida de esa manera, se vulneraría el principio democrático, consagrado en el artículo 1 Superior. De allí que la Ley 963 de 2005 no puede ser entendida como una cesión al ejercicio de la soberanía nacional. [...]. Lo que sucede, se insiste, es que se está ante un contrato, en virtud del cual el Estado se comprometió a mantener unas condiciones normativas favorables, aplicables únicamente en el contexto de dicho acuerdo particular, equilibrio económico que podría verse alterado por la adopción de una norma aplicable a la inversión realizada, caso en el cual el Estado podría ver comprometida su responsabilidad (énfasis añadido)". 
nocidas tanto en el Código Orgánico de la Producción, Comercio e Inversiones, como en la Ley APP. Sin embargo, a efectos de este artículo corresponde centrarse exclusivamente en el tratamiento al amparo de la Ley APP.

El artículo 15 de la ley en mención prescribe la posibilidad de incluir en el contrato de gestión delegada una cláusula de estabilidad. Es así que en su tenor literal prescribe:

La estabilidad jurídica que se garantiza en esta Ley se extiende a los aspectos regulatorios sectoriales y específicos que hayan sido declarados como esenciales en los correspondientes contratos de gestión delegada.

$[\ldots]$

La estabilidad jurídica no recaerá sobre las normas declaradas inconstitucionales o ilegales por el tribunal competente, durante la vigencia de los contratos de gestión delegada $[\ldots]^{32}$.

Se evidencia de este modo que la Ley APP contempla una cláusula de congelamiento parcial, pues no otorga inmutabilidad sobre todo el ordenamiento jurídico sino que exclusivamente frente a los aspectos sectoriales que hayan sido declarados como esenciales en el contrato de gestión delegada.

En este sentido, el artículo 10 del Reglamento a la Ley APP es claro al establecer que "[1]a estabilidad jurídica asegura la permanencia de los aspectos regulatorios sectoriales y específicos que hayan sido declarados como esenciales en el contrato [... $]^{\prime \prime 33}$. Es decir que si el inversionista desea contar con una protección de estabilidad no bastará la inclusión de una cláusula de estabilidad en sentido amplio, pues si en esta no se detalla cuáles son las normas regulatorias sobre las cuales se desea estabilidad, la cláusula será ineficaz.

Por otro lado, cabe señalar que en Ecuador no existe cabida para sostener que la cláusula de estabilidad implica un menos-

32. Ley APP, N. 1, Art. 15 .

33. Reglamento a la Ley Orgánica de Incentivos para Asociaciones Público-Privadas y la Inversión Extranjera (Reglamento a la Ley APP), Art. 10, RO No. 786, 29/06/2016. 
cabo a la soberanía estatal, pues el último inciso del artículo 10 del Reglamento a la Ley APP es claro al establecer que "[1]a señalada garantía [de estabilidad] no implica la renuncia del Estado al ejercicio de su capacidad regulatoria" ${ }^{\prime 3}$. Es de este modo que es posible evidenciar la diferenciación que existe entre el compromiso a no regular y el compromiso a no aplicar la normativa en cuestión.

A la luz del Reglamento a la Ley APP no queda duda que al suscribir una cláusula de estabilidad jurídica el Estado mantiene su potestad de emitir cuanta regulación desee. Esta cláusula no afecta, entonces, la potestad legislativa o regulatoria del Estado, sino que tan solo impide que la normativa, sobre la cual se pactó estabilidad, sea aplicada al inversionista con el cual se ha suscrito dicha cláusula, quedando plenamente aplicable en otros casos.

En la práctica, algunos contratos de gestión delegada suscritos en el país, desde la entrada en vigencia de la Ley APP, han incluido una cláusula en los siguientes términos ${ }^{35}$ :

79. Equilibrio Económico-Financiero del Acuerdo. [...] Por medio del presente las Partes acuerdan que la Entidad Delegante compensará al Gestor Privado solamente para restaurar el equilibrio económico-financiero del Acuerdo, en los siguientes casos: "Variaciones Relevantes": Cualquier cambio posterior al 07 de octubre de 2016 (fecha de presentación de la propuesta) en la Legislación aplicable o la práctica de una entidad gubernamental que incluya la legislación fiscal o la imposición de un impuesto, o cualquier acto, orden u omisión de la administración o de cualquier entidad gubernamental que afecte negativamente al Gestor Privado, incluyendo pero sin limitarse a sus ingresos, gastos, ganancias o que incremente sus responsabilidades. Para evitar dudas, la Legislación Aplicable incluirá toda ley, ordenanza, decreto, regulación o estatuto, o toda norma, circular, directiva o cualquier licencia, autorización, permiso,

34. Reglamento a la Ley APP, N. 33, Art. 10.

35. La cláusula citada es la contenida en el "Contrato de Gestión Delegada para el Diseño y Planificación, Financiación, Equipamiento y Construcción de Obras Adicionales, Operación y Mantenimiento de la Terminal Portuaria de Manta”, esta es similar a la cláusula de otros contratos de gestión delegada, tales como los suscritos con DPWORLD POSORJA S.A. y YILPORT TERMINAL OPERATION. 
concesión o demás aprobaciones emitidas por cualquier Autoridad Competente [...] (énfasis añadido) ${ }^{36}$.

El contenido de esta cláusula amerita ciertas observaciones ${ }^{37}$, pues a través de ella se evidencia que: (i) Para que surja el deber de indemnizar al inversionista es fundamental que el cambio en la legislación afecte al gestor privado, es decir, que sea efectivamente aplicada la modificación en cuestión. Ello confirma que la suscripción de una cláusula de estabilidad no compromete la soberanía estatal y que el Estado está en capacidad de realizar todos los cambios legislativos que desee (e inclusive aplicarlos al inversionista), bajo la condición de indemnizarlo en caso de generarle un daño; (ii) La Entidad Delegante expresamente asume el deber de indemnizar, inclusive en caso que la normativa aplicable sea modificada por otra autoridad estatal, lo cual atribuye al inversionista mayor seguridad, pues la redacción de la cláusula no da cabida a que el Estado evada su obligación indemnizatoria alegando falta de causalidad. Esta situación, en la que la estabilidad jurídica la irrumpe una autoridad distinta a la entidad delegante será analizada con mayor detalle en la sección 3.4.2, y; (iii) Al contemplarse expresamente como uno de los supuestos que obliga a la Entidad Delegante indemnizar al inversionista, los cambios en la legislación fiscal o la política impositiva; se evidencia con claridad la separación que existe entre el deber indemnizatorio de la Entidad Delegante (aspecto arbitrable) y el asunto tributario (aspecto inarbitrable por disposición del artículo 20.2 de la Ley APP) (sección 4.3.2).

36. Escritura Pública No. 20161308006P02095, suscrita el 16/12/2016 ante el Notario Sexto de Manta, la cual contiene el Contrato de Gestión Delegada para el Diseño y Planificación, Financiación, Equipamiento y Construcción de Obras Adicionales, Operación y Mantenimiento de la Terminal Portuaria de Manta. Cláusula 79, p. 174.

37. Véase, N. 74. 


\section{NATURAleza de los COMPROMISOS ASUMIDOS POR EL ESTADO A TRAVÉS DE LA SUSCRIPCIÓN DE UNA CLÁUSULA DE ESTABILIDAD JURÍDICA Y LOS EFECTOS DE SU INCUMPLIMIENTO}

En esta sección se evidenciará que, al suscribir una cláusula de estabilidad jurídica, el Estado asume una obligación de no hacer [3.1]. El incumplimiento a dicha obligación no se da por la mera promulgación de una nueva ley [3.2], sino que requiere de un acto administrativo mediante el cual dicha ley sea aplicada al inversionista [3.3]. Finalmente, se analizarán las particularidades del régimen indemnizatorio ante el incumplimiento a la cláusula de estabilidad [3.4].

\subsection{La cláusula de estabilidad como una obligación de no hacer del Estado}

Conforme al artículo 1467 del Código Civil toda obligación debe tener una prestación de dar, hacer o no hacer. Estas últimas consisten en una abstención a cargo del deudor ${ }^{38}$. Es así que

[e]l objeto de la obligación de no hacer es una omisión: abstenerse de ejecutar un hecho que de no existir la obligación podría hacerse. Es como una limitación a la libertad de actuar de una persona, que debe privarse de hacer ciertas cosas que normalmente y a no mediar la obligación podría llevar a cabo ${ }^{39}$.

En efecto, la "obligación de no hacer es aquella que tiene por objeto la no ejecución de un hecho por parte del deudor, aquella que le impone al deudor la no ejecución de un hecho que sin la obligación le sería lícito hacer" ${ }^{\prime 4}$. En consecuencia, este tipo de obligaciones se cumplen mediante la abstención por

\footnotetext{
38. Véase, A. Alessandri, Teoría de las Obligaciones, Tomo I, Nascimento, 1936, p. 26; M. CoHEN CHICurel, Compendio de Derecho de las Obligaciones, Porrúa, 2014, p. 23; L. DíEz PicAzo y A. Gullón, Sistema de Derecho Civil, 11va Ed., Tomo 1, Tecnos, 2016, p. 127; y, G. Ospina Fernández, Régimen General de las Obligaciones, 6ta Ed., Temis, 1998, p. 24.

39. R. Abeliuk, Las Obligaciones, 4ta Ed., Tomo I, Dislexia Virtual, p. 220.

40. A. Alessandri, N. 38, p. 26.
} 
parte del deudor, en los términos que se haya convenido por las partes.

Al pactar una cláusula de estabilidad jurídica "el Estado se obliga a través del acuerdo contenido en la cláusula a no aplicar, al contrato en particular, cualquier cambio posterior en la legislación" (énfasis añadido) ${ }^{41}$. Así:

La principal implicación de este tipo de cláusulas de estabilidad sugiere que el Estado receptor prometa que las subsecuentes legislaciones $\mathrm{u}$ otro tipo de intervención por el ejercicio de los poderes estatales no le serán aplicables a las relaciones entre las partes del acuerdo durante el periodo de duración del mismo [...] (énfasis añadido) ${ }^{42}$.

En este sentido, la Corte Constitucional de Colombia resolvió que:

[a través de] los contratos de estabilidad jurídica no se les garantiza a los inversionistas la inmodificabilidad de la ley, sino que se les asegura la permanencia, dentro los términos del acuerdo celebrado con el Estado, las mismas condiciones legales existentes al momento de la celebración de aquél ${ }^{43}$.

A través del compromiso de estabilidad jurídica:

[...] el Estado garantiza a los inversionistas que los suscriban, que si durante su vigencia se modifica en forma adversa a estos alguna de las normas que haya sido identificada en los contratos como determinante de la inversión, los inversionistas tendrán derecho a que se les continúen aplicando dichas normas por el término de duración del contrato respectivo ${ }^{44}$.

Este derecho que tienen los inversionistas para que les sean aplicadas las normas vigentes al momento de la inversión tiene como correlativa obligación la abstención por parte del Estado de

41. Traducción libre. M. Sornarajah, N. 11, p. 281.

42. D. C. Bernal, N. 3, p. 154.

43. Corte Constitucional de la República de Colombia, N. 31.

44. A. Marrugo, Contratos de estabilidad jurídica en Colombia. Análisis de la ley 963 de 2005, Tesis de Grado. Universidad de Cartagena, 2012, p. 5. 
aplicar la normativa que, tras la suscripción del acuerdo de inversión, haya sufrido alteraciones.

De este modo, se evidencia que al incorporar una cláusula de estabilidad el Estado asume un deber de abstención que se traduce en la no aplicación, al inversionista, de la normativa que no estaba vigente al momento de la inversión. Esto quiere decir que la obligación que asume el Estado a través de una cláusula de estabilidad tiene como prestación un no hacer. Por lo tanto, el incumplimiento y las acciones que tiene el inversionista en calidad de acreedor serán aquellas que correspondan a este tipo de obligaciones. Para ello deberá tomarse en consideración las particularidades que surgen en los casos en los que no es la Entidad Delegante quien irrumpe la estabilidad, las cuales serán analizadas en la sección 3.4.2 de este artículo.

\subsection{El incumplimiento del Estado a la cláusula de estabili- dad se da mediante la aplicación de la ley, no por su mera promulgación}

El incumplimiento a las obligaciones de no hacer se configura a través de la realización, por parte del deudor, del acto que prometió abstenerse ${ }^{45}$. Así, "la obligación de no hacer se viola por el solo hecho de que el deudor ejecute el hecho prohibido" ${ }^{\prime 46}$. El hecho prohibido para el Estado es la aplicación, al inversionista, de toda alteración que haya sufrido la normativa estabilizada. Entonces, el incumplimiento del Estado a la cláusula de estabilidad se traduce en la aplicación de estas normas al inversor. Si bien aquella conclusión resulta lógica, no es la única.

Calero TAfur, al determinar en qué momento se da el incumplimiento del Estado a la cláusula de estabilidad menciona que se puede optar por dos vías ${ }^{47}$ : (i) una interpretación literal del

45. Véase, O. BARBERo, Introducción al Derecho Privado, Editorial Iuris, 2004, p. 193 y L. Claro SolAR, Explicaciones de Derecho Civil Chileno y Comparado, Vol. 5, Editorial Jurídica Chile, 1992, p. 700.

46. A. Alessandri, N. 38, p. 72.

47. M. A. Calero Tafur, El Contrato Estatal de Estabilidad Jurídica, Tesis de postgrado. Universidad del Rosario, 2014, pp. 90-93. 
contrato de inversión o (ii) una interpretación de la sentencia C320 de la Corte Constitucional de Colombia (a la cual se ha hecho referencia en líneas anteriores de este artículo). Según la primera alternativa el incumplimiento del Estado consiste en "[...] el hecho de aplicar al inversionista una nueva norma que desmejore sus intereses por ser contraria a otra, previamente 'congelada' para él"48 (énfasis añadido). En cambio, considera que a la luz del precedente de la Corte Constitucional, "el incumplimiento coincide con el cambio de legislación, siempre que este sea adverso a los intereses de un inversionista" ${ }^{49}$.

La segunda interpretación se fundamenta en el hecho que en su sentencia, la Corte Constitucional señaló que: "el artículo $1^{\text {o de }}$ la Ley 963 de 2005 [referente a la estabilidad jurídica] no habilita o faculta a un determinado grupo de personas para que incumplan la Constitución o la ley ${ }^{\prime \prime 50}$. Al amparo de esta aclaración, CALERO TAFUR considera que al no estar facultado a incumplir la ley, por su simple promulgación, el inversionista debe acatarla y que, en consecuencia, todo cambio en la legislación siempre le será aplicable.

Sin perjuicio del hecho que en Ecuador el precedente de la Corte Constitucional colombiana no tenga fuerza vinculante, este trabajo sostiene que la interpretación realizada por CALERO TAFUR a dicha sentencia no es el única plausible. Si bien la Corte Constitucional menciona que al amparo de una cláusula de estabilidad el inversionista no está facultado a incumplir la ley, ello no quiere decir que la simple modificación de una ley sobre la cual rige estabilidad sea en sí un incumplimiento a la cláusula de estabilidad.

Al contrario, para que alguien pueda incumplir una ley debe encontrarse bajo sus efectos. Es decir, nadie puede incumplir algo que no le es aplicado. En este sentido, si la norma modificada no es aplicada al inversionista, este, bajo ningún supuesto puede in-

48. Ídem, p. 91.

49. Ibídem.

50. Corte Constitucional de la República de Colombia, Sentencia C-320, N. 31. 
cumplirla. A la luz de este razonamiento, otra interpretación a la sentencia de la Corte Constitucional de Colombia permite concluir que la afirmación de la Corte consiste en que si el Estado, en contravención a su obligación de no hacer, decide aplicar al inversionista la norma modificada, este no puede ampararse en la cláusula de estabilidad para incumplir aquella norma. En este caso, tal como lo menciona la Corte, lo que el inversionista puede hacer ante el incumplimiento del Estado, es exigir la correspondiente indemnización ${ }^{51}$.

Esta interpretación se sustenta en el hecho que, como se mencionó en líneas anteriores, en la misma sentencia la Corte Constitucional señaló (i) que a través de una cláusula de estabilidad se garantiza al inversor la permanencia de las condiciones legales, no la inmodificabilidad de la ley; y, (ii) que la cláusula de estabilidad no limita la potestad normativa de los órganos del Estado. Por tanto, la Corte reconoce que pese a la existencia de una cláusula de estabilidad el Estado puede modificar la ley. Esta modificación no puede, entonces, ser entendida como un incumplimiento, pues ello nos llevaría al absurdo de considerar que aún si la norma no es aplicada, pero sí modificada, existe un incumplimiento por parte del Estado.

De este modo, no es posible afirmar que el incumplimiento del Estado consiste en la simple promulgación de una nueva ley o en la modificación de otra. Ello debido a que "la violación de los convenios de estabilidad jurídica se genera [...] por el incumplimiento por parte del estado cuando pretenda aplicar un régimen legal distinto al estabilizado alterando unilateralmente las normas que fueran materia de las garantías de estabilidad"52.

Así, al amparo de la teoría de las obligaciones, y tomando en cuenta que al pactar una cláusula de estabilidad, el Estado asume una obligación de no hacer y que el hecho prohibido consiste en aplicar la normativa modificada al inversionista; el incumpli-

51. Véase, N. 31.

52. J. DANÓs ORDÓÑEZ, "Los convenios de estabilidad jurídica o también denominados contratos leyes en el Perú", Ius et Veritas, No. 46, 2013, p. 269. 
miento no puede darse de otra forma que mediante la aplicación de la ley que se prometió no sería aplicada.

\subsection{El incumplimiento del Estado se materializa a través de actos administrativos}

Puesto que la promulgación de una nueva ley no implica, per se, una inobservancia por parte del Estado a la cláusula de estabilidad, entonces, para que exista incumplimiento es necesario que medie un acto de aplicación de esta ley. De acuerdo al artículo 98 del Código Orgánico Administrativo (en adelante, COA), el acto administrativo es la "declaración unilateral de voluntad, efectuada en ejercicio de la función administrativa que produce efectos jurídicos individuales o generales, siempre que se agote con su cumplimiento y de forma directa" (énfasis añadido) ${ }^{53}$.

Los actos administrativos están encaminados a producir efectos jurídicos de manera individual ${ }^{54}$. Es así que se definen como "toda clase de declaración jurídica, unilateral y ejecutiva, en virtud de la cual, la Administración tiende a crear, modificar o extinguir situaciones jurídicas subjetivas" (énfasis añadido) ${ }^{55}$.

El acto mediante el cual el Estado incumple su obligación es un acto creador de una situación jurídica individual. En efecto, a través de este el Estado aplica al inversionista una ley cuyos efectos no le eran aplicables, creando de este modo una nueva situación jurídica para el inversionista en cuestión. Esta modificación es personal, pues era ese inversionista en particular el que no se encontraba bajo los efectos de la norma y, por tanto, es únicamente él quien requiere de un acto de aplicación que lo obligue a acatar la norma modificada. De no mediar este acto administra-

53. Código Orgánico Administrativo (COA), Art. 98, RO Sup. No. 31, 07/07/2017. Los actos administrativos se diferencian de los actos normativos en la medida en la que los segundos, tal como lo prescribe el artículo 128 del COA, no producen efectos de forma individual, solo general. Por esta razón los actos normativos entran en la primera categoría de la clasificación de los actos jurídicos.

54. Véase, J. C. Cassagne, El Acto Administrativo, Themis, 2013, pp. 17-25; J. Comadira, Derecho Administrativo, Abeledo-Perrot, 2003, pp. 4-7; y, E. PÉREZ, "La noción de acto administrativo en el Derecho Público Ecuatoriano", Iuris Dictio, No. 5, 2005, p. 79.

55. P. Jaramillo, Derecho Público Interno, Casa de la Cultura Ecuatoriana, 1953, p. 273. 
tivo, el inversionista, al verse excluido de la aplicación de la norma, no se encuentra bajo sus efectos.

En consecuencia, es a través de un acto administrativo que el Estado incumple la cláusula de estabilidad, al modificar a través de este la situación jurídica del inversionista. Esta conclusión es relevante a efectos de analizar en la sección 4.2 si someter a arbitraje el incumplimiento a la cláusula de estabilidad es un caso de arbitrabilidad de actos administrativos.

\subsection{El régimen indemnizatorio ante el incumplimiento del Es- tado a la cláusula de estabilidad}

En primer lugar, se estudiará el régimen indemnizatorio ante el incumplimiento de las obligaciones de no hacer [3.4.1]. Sobre la base de ello se analizará si, ante el incumplimiento a la cláusula de estabilidad, cabe la destrucción del hecho prohibido [3.4.2]; $\mathrm{y}$, qué sucede si no media dicha destrucción [3.4.3].

\subsubsection{El régimen indemnizatorio ante el incumplimiento de las obligaciones de no hacer}

Al contraer una obligación de no hacer, el deudor se abstiene de realizar determinado hecho, pero, ¿qué sucede ante la realización del hecho prohibido? El artículo 1571 del Código Civil señala que:

Toda obligación de no hacer una cosa se resuelve en la de indemnizar los perjuicios, si el deudor contraviene y no puede deshacerse lo hecho.

Pudiendo destruirse la cosa hecha, y siendo su destrucción necesaria para el objeto que se tuvo en mira al celebrar el contrato, estará el deudor obligado a ella, o autorizado el acreedor para que la lleve a ejecución a expensas del deudor.

Si dicho objeto puede obtenerse cumplidamente por otros medios, será oído el deudor que se allane a prestarlos.

El acreedor quedará de todos modos indemne ${ }^{56}$.

56. Código Civil, Art. 1571, RO Sup. No. 46, 24/06/2005. 
En este sentido, se evidencia que "las obligaciones de no hacer llevan implícito la obligación de indemnizar [...] pero únicamente cuando no se puede deshacer lo hecho" ${ }^{\prime \prime 7}$.

A la luz del artículo 1571 del Código Civil, para determinar qué opciones tiene el acreedor es imprescindible analizar si cabe la destrucción del hecho prohibido. La necesidad de preferir la destrucción del hecho prohibido radica en "la fuerza obligatoria del contrato [la cual] exige que se asegure el cumplimiento de la obligación" ${ }^{58}$. En caso de ser posible la destrucción del hecho, "la ejecución forzada consistirá en la destrucción de lo hecho a costa del que estaba obligado a no hacerlo" ${ }^{\prime 59}$.

Es importante señalar que también es posible que "la destrucción del hecho prohibido se sustituy[a] por algo que suple cumplidamente el fin"60, en cuyo caso estamos ante un cumplimiento por analogía, toda vez que el deudor logra revertir los efectos del hecho dañoso ${ }^{61}$. En estos casos nos encontramos ante situaciones que si bien no equivalen al cumplimiento en naturaleza (es decir a la abstención del hecho prohibido) "[...] tienden a imitarlo, y por ello son casos de cumplimiento forzado y no de indemnización" ${ }^{\prime \prime 2}$.

No obstante, existen ocasiones en las que no es posible alcanzar el cumplimiento forzado de una obligación de no hacer ${ }^{63}$. En estos escenarios, una vez incumplido el deber de abstención "la ejecución forzada no podrá consistir en el cumplimiento de la obligación, por lo tanto el pago de una cantidad de dinero a título de indemnización por los daños y perjuicios causados hará sus veces" ${ }^{\prime \prime}$. Ello se debe a que "la obligación que uno se ha impuesto de no hacer alguna cosa, produce asimismo el efecto de que con-

57. Corte Nacional de Justicia, Sala Temporal Especializada de lo Civil y Mercantil, Juicio No. 710-2009, 31/10/2012.

58. L. Claro Solar, N. 45, p. 700.

59. S. Azúa Reyes, Teoría General de las Obligaciones, Porrúa, 1997, p. 26.

60. R. Moeller Gómez, "La indenmización de perjuicios", Revista Jurídica Online, p. 326, $<$ goo.gl/5WTFy 7 .

61. Ibídem.

62. R. Abeliuk, N. 39, p. 132.

63. M. Bejerano SÁnchez, Obligaciones civiles, Oxford University Press, 1999, p. 269.

64. S. AzÚA REYES, N. 59, p. 26. 
traviniendo el deudor a lo pactado, estará tenido al pago de todos los daños y perjuicios ocasionados al acreedor con la ejecución del hecho cuya omisión se le había prometido" ${ }^{65}$.

Es importante resaltar el último inciso del artículo 1571 del Código Civil en virtud del cual "[e]l acreedor quedará de todos modos indemne" ${ }^{\prime \prime 6}$. De este se destaca la necesidad de reparar al acreedor cualquier daño que haya sufrido por la realización del hecho prohibido, sea que esta reparación se alcance por medio de la destrucción del hecho o a través del pago de una indemnización. Una vez establecidas ambas alternativas, cabe analizar a cuál de ellas puede recurrir el inversionista ante el incumplimiento a la cláusula de estabilidad.

\subsection{2 ¿Cabe la destrucción del hecho prohibido ante el incumplimiento a la cláusula de estabilidad?}

Al irrumpir la estabilidad jurídica existe una alteración del equilibrio económico del contrato. Ello debido a que los riesgos y cargas se fijaron bajo el entendido que ninguna modificación en la normativa estabilizada afectaría la inversión. En consecuencia, para revertir los daños generados, es necesario que se retome el equilibrio económico del contrato, ya sea dejando sin efecto el acto administrativo mediante el cual se alteró la estabilidad jurídica o renegociando el contrato. Estas opciones dependerán de quién alteró la estabilidad jurídica, la Entidad Delegante u otra entidad del Estado.

Si fue la Entidad Delegante quien afectó la estabilidad, es posible que exista una revocatoria del acto administrativo mediante el cual se incumplió la obligación y que de este modo se destruyan los efectos del hecho dañoso. El artículo 103 del COA establece que entre las formas por las que se puede extinguir un acto administrativo están (i) las razones de legitimidad y (ii) la revocatoria ${ }^{67}$.

65. J. РотніЕR, Tratado de las Obligaciones, Rogers, 1839, p. 88.

66. Código Civil, N. 56, Art. 1571.

67. El artículo 103 del COA prescribe que "El acto administrativo se extingue por: (1) Razones de legiti- 
Respecto a la primera es importante tomar en cuenta que no en todos los casos será posible atacar el acto administrativo por su ilegitimidad. Ello debido a que, al suscribir una cláusula de estabilidad, el Estado conserva intacta la facultad de emitir o modificar su legislación. En consecuencia, es plenamente legítimo que el Estado, en uso de sus facultades soberanas, aplique sus leyes incluso a un inversionista protegido por una cláusula de estabilidad. Así, pese a que el acto administrativo mediante el cual se altera la estabilidad jurídica genere un daño, y una correspondiente responsabilidad de la Entidad Delegante, dicho acto es legítimo.

La legitimidad de este acto solo podrá cuestionarse si ocurre alguna de las causales contempladas en el artículo 105 del $\mathrm{COA}^{68}$. Es por ello que, por regla general, el acto por el cual se irrumpe la estabilidad jurídica no es un acto con vicios de ilegitimidad. Siendo así, es del todo probable que ante el incumplimiento del Estado a la cláusula de estabilidad no quepa la extinción del acto administrativo por razones de legitimidad. De ser así, cabe analizar, entonces, la viabilidad de la revocatoria.

El artículo 118 del COA prescribe la posibilidad de que la Administración revoque el acto administrativo desfavorable para el administrado en aquellos casos en los que "tal revocatoria no constituya dispensa o exención no permitida por el ordenamiento jurídico o sea contraria al principio de igualdad, al interés público o al ordenamiento jurídico" ${ }^{\prime \prime}$. Es claro que la Ley APP permite incluir en los contratos de gestión delegada una cláusula de esta-

midad, cuando se declara su nulidad; (2) Revocatoria, en los casos previstos en este Código; (3) Cumplimiento, cuando se trata de un acto administrativo cuyos efectos se agotan; (4) Caducidad, cuando se verifica la condición resolutoria o se cumple el plazo previsto en el mismo acto administrativo o su régimen específico; (5) Ejecución de los derechos o cumplimiento de las obligaciones que se deriven de él, de conformidad con la ley, si no se ha previsto un régimen específico".

68. El artículo 105 contempla las siguientes causales de nulidad del acto administrativo: (i) sea contrario a la Constitución y a la ley; (ii) viole los fines para los que el ordenamiento jurídico ha otorgado la competencia al órgano o entidad que lo expide; (iii) se dictó sin competencia por razón de la materia, territorio o tiempo; (iv) se dictó fuera del tiempo para ejercer la competencia, siempre que el acto sea gravoso para el interesado; (v) determine actuaciones imposibles; (vi) resulte contrario al acto administrativo presunto cuando se haya producido el silencio administrativo positivo; (vii) se origine en hechos que constituyan una infracción penal declarada en sentencia judicial ejecutoriada; y, (viii) se origine de modo principal en un acto de simple administración.

69. COA, N. 53, Art. 118. 
bilidad jurídica, por lo que si se revoca el acto en consideración a la estabilidad jurídica que la propia Entidad Delegante garantizó en el contrato, tal revocatoria se sustentaría precisamente en una exención permitida por el ordenamiento jurídico y que bajo ningún concepto podría contravenirlo.

Al respecto, vale la pena aclarar que la revocatoria del acto no se fundamenta en que el contrato de gestión delegada prime por sobre la ley. La cláusula de estabilidad jurídica no puede ser entendida como una simple disposición contractual, sino que debe recordarse que el propio ordenamiento jurídico habilita al Estado a pactar este tipo de cláusulas, precisamente, en uso de sus facultades soberanas. Por lo tanto, es viable que la Entidad Delegante revoque su propio acto administrativo, en consideración a las disposiciones legales que le facultaron inicialmente a asumir los compromisos que derivan de la cláusula de estabilidad. La revocatoria es, entonces, una opción idónea para destruir el hecho prohibido, siempre y cuando, claro está, los daños generados por el acto sean revertidos mediante su revocatoria, pues, si no es así, la revocatoria del acto resultará insuficiente, por lo que persistiría el deber del Estado de indemnizar los daños generados.

Por otro lado, cabe señalar que la revocatoria se presenta como una alternativa plausible para destruir el hecho prohibido solamente si la Entidad Delegante es quien lo emitió, pues no está facultada a revocar los actos emitidos por otro órgano del Estado. Así, si la revocatoria no depende de la propia Entidad Delegante mal se haría en esperar que el inversionista deba acudir ante otra entidad, con la cual no suscribió el contrato de gestión delegada, para pretender dicha revocatoria, pues conforme lo prescrito en el artículo 1571 del Código Civil la destrucción del hecho prohibido le compete al deudor (es decir, la Entidad Delegante) y al acreedor en aquellos casos en los que esté autorizado. Así, en ningún supuesto tal destrucción está a cargo de un tercero. En consecuencia, si la Entidad Delegante no emitió el acto, la revocatoria no es una alternativa para destruir el hecho prohibido. 
Sin embargo, en estos casos es posible que, sin perjuicio de que no se destruya el acto administrativo, exista una destrucción de los efectos dañinos de este acto. Es así que aún en los casos en los que es otra entidad del Estado quien altera la estabilidad jurídica, la Entidad Delegante está en la posibilidad de destruir, por equivalencia, el hecho prohibido, al retomar el equilibrio económico del contrato.

En todo contrato administrativo rige el principio de equilibrio financiero ${ }^{70}$, el cual "implica el mantenimiento de la equivalencia entre las ventajas y las cargas como habían sido calculadas [...] en el momento de perfeccionamiento el contrato"71. En consecuencia,

[...] cuando la conmutatividad de las prestaciones establecida en la celebración del contrato resulte gravemente afectada, nace tanto para el contratista como para la Administración el derecho al restablecimiento de la ecuación financiera del contrato, correlativamente, surge en cabeza del contratante correspondiente el deber de la restauración del mismo (énfasis añadido ${ }^{72}$.

Al incorporar una cláusula de estabilidad en un contrato de gestión delegada, el inversionista calcula los riesgos asumiendo la permanencia de la normativa que fue estabilizada. En consecuencia, la aplicación de cualquier variación a esta normativa se traduce en un actual o eventual quiebre en el equilibrio económico financiero, existiendo la posibilidad de que el cumplimiento del inversionista se vuelva más gravoso. Cuando tal aplicación se realiza por una institución distinta a la Entidad Delegante, la única forma que tiene la Entidad Delegante, en su calidad de deudor de la obligación contenida en la cláusula de estabilidad jurídica, para destruir los efectos del hecho dañoso, es retomar el equilibrio económico del contrato. En caso de no hacerlo, al no

70. Véase, J. PARRA BeníteZ, La teoría del hecho del príncipe y la teoría de la imprevisión como instrumentos que restablecen el equilibrio económico contractual en los Contratos Estatales, $<$ goo.gl/wBDkvJ>, pp. 185-186.

71. Corte Suprema de Justicia, Segunda Sala de lo Civil y Mercantil, Juicio No. 409-2007, 04/12/2007.

72. M. CANAL-SILVA, "La aplicación del principio del equilibrio económico a contratos estatales sometidos al régimen normativo del derecho privado", Revista Digital de Derecho Administrativo, No. 15, 2016, p. 147. 
existir destrucción de los efectos del hecho dañoso, le corresponderá entonces indemnizar al inversionista el daño generado.

Al respecto vale señalar que el procurar la destrucción del hecho prohibido por equivalencia, mediante la restauración del equilibrio económico del contrato, va de la mano con lo prescrito en el artículo 20.1 de la Ley APP. Según este artículo "[c]uando la parte que se estime afectada comunique a la otra el objeto de la controversia, estas podrán solucionar la disputa mediante diálogos directos o mediación"73. En efecto, antes de accionar la vía arbitral el inversionista podrá en el marco de una negociación (ya sea por diálogos directos o dentro de un proceso de mediación) procurar que se retome el equilibrio económico del contrato. Si tal renegociación es alcanzada, entonces habrá una destrucción de los efectos del hecho dañoso, lo que implica que no existe daño que deba ser indemnizado y como tal no existe controversia que pueda ser sometida a arbitraje. En cambio, si la Entidad Delegante no retoma el equilibrio contractual, existe un incumplimiento y un respectivo daño que debe ser indemnizado.

\subsubsection{En caso de no mediar destrucción del hecho prohibido, la Entidad Delegante debe indemnizar al inversionista}

El contrato de gestión delegada se suscribe entre el gestor privado -inversionista- y la Entidad Delegante, por lo que al ser la Entidad Delegante quien contrajo las obligaciones del contrato de gestión delegada, es quien al suscribir la cláusula de estabilidad asume la respectiva obligación de indemnización. En consecuencia, si la Entidad Delegante no destruye el hecho prohibido, el inversionista tiene derecho a que la Entidad Delegante, en su calidad de deudora, lo indemnice.

La Entidad Delegante está obligada a indemnizar al inversionista por los daños generados, independientemente de si fue ella, u otra entidad del Estado, quien alteró la estabilidad jurídica del contrato. Si bien el aplicar el inversionista normativa que no

73. Ley APP, N. 1, Art. 20(1). 
estaba vigente al momento de la inversión es un acto que no depende necesariamente de la Entidad Delegante, ello no la exime de su deber de indemnización. De hecho, este deber indemnizatorio se ha incluido expresamente en algunos de los contratos de gestión delegada suscritos en el país, tal como se señaló en la sección $2.3^{74}$.

Es claro que la Entidad Delegante no es siempre la encargada de aplicar la normativa estabilizada, por lo que no tiene sentido pensar que la obligación de indemnizar al inversionista sea exigible solo en casos en los que sea la propia Entidad Delegante quien altere la estabilidad jurídica del contrato. Al contrario, mediante la suscripción de una cláusula de estabilidad jurídica, la Entidad Delegante garantiza al inversionista que aún en los casos en los que sea otra entidad del Estado quien altere la estabilidad jurídica, la Entidad Delegante hará frente a los daños causados. Si no fuere así ¿cuál sería entonces la garantía de pactar una cláusula de estabilidad?

Por tanto, a través de la cláusula de estabilidad jurídica la Entidad Delegante asume la responsabilidad por todo hecho ajeno mediante el cual se aplique, al inversionista, cualquier modificación en la normativa estabilizada. Precisamente,

74. En este punto vale la pena señalar que, en atención a los términos en los que se ha pactado la estabilidad en algunos contratos de gestión delegada en Ecuador (véase notas al pie N. 35 y 36) se podría sostener que en realidad el Estado asume una obligación de hacer, cuya prestación es indemnizar al inversionista en caso que algún cambio en la normativa estabilizada lo afecte. A pesar de ello, la postura de este trabajo es que, independientemente de la redacción empleada, la obligación del Estado es un "no hacer" (no aplicar los cambios en la normativa estabilizada). La obligación indemnizatoria contenida en la cláusula citada no es más que una positivización de los efectos que tiene el incumplir la estabilidad jurídica; situación que otorga aún más certeza al inversionista, pues la redacción de la cláusula no da cabida a que el Estado evada su obligación indemnizatoria ni siquiera alegando falta de causalidad, puesto que la asume expresamente en casos en los que es otra entidad estatal quien altera la estabilidad. Como se señala a lo largo de la sección 3.4 de este artículo, el régimen indemnizatorio de las obligaciones de no hacer implica que en caso de realizarse el hecho prohibido (en este caso, aplicar los cambios en la legislación estabilizada), el deudor está en la obligación de indemnizar. El hecho que en las cláusulas de estabilidad pactadas en algunos contratos de gestión delegada en Ecuador, se contemple expresamente el deber indemnizatorio del Estado en caso de incumplimiento, no cambia la naturaleza de la prestación detrás de la cláusula de estabilidad jurídica. Así, sin perjuicio de la redacción empleada, el Estado, al garantizar estabilidad jurídica al inversionista, debe abstenerse de aplicarle cualquier modificación que se dé en la normativa estabilizada, pues, de no hacerlo (incumplir la prestación de no hacer) estará obligado a indemnizar. Esta aclaración resulta relevante a fin de ratificar que el régimen aplicable en caso de incumplimiento del Estado será el previsto para las obligaciones de no hacer, por lo que resulta preciso analizar los supuestos de destrucción del hecho prohibido previstos en la sección 3.4.2. 
[en los casos de] responsabilidad contractual por el hecho ajeno, la fuente de imputación al principal deudor no radicaría en su acto personal, sino en aquél del tercero por quien responde. Y, como es evidente, el deudor no respondería por cualquier tercero involucrado en la ejecución de la obligación contractual, dependerá si el deudor participó en dicha elección. Sólo en las hipótesis en que el deudor principal haya introducido -organizado- una ejecución mediante la participación de los terceros deberá responder por estos (énfasis añadido) ${ }^{75}$.

Esta es la situación que se da al pactar una cláusula de estabilidad jurídica. Al otorgar al inversionista la garantía de que los cambios a la legislación estabilizada no le serán aplicados, la Entidad Delegante asume la responsabilidad contractual por los daños que se generen en caso de irrumpir aquella estabilidad.

La modificación y aplicación de la normativa estabilizada no está necesariamente en manos de la Entidad Delegante. De hecho, es por ello que desde la suscripción del contrato, la Entidad Delegante sabe que la ejecución de su obligación de no aplicación no depende únicamente de ella, ya que existen otras entidades del Estado que están en la posibilidad de aplicar al inversionista la normativa estabilizada. De esta forma, la ejecución de la obligación de no hacer, a cargo de la Entidad Delegante, requiere a su vez de la participación de otros actores estatales; actores que la Entidad Delegante reconoció al acordar, en el contrato de gestión delegada, el alcance de la cláusula de estabilidad. Así, la obligación que asume al incluir una cláusula de estabilidad jurídica conlleva la responsabilidad de indemnizar al inversionista también por los hechos ajenos que generen una inobservancia a su obligación. En consecuencia, no existe razón para desconocer la responsabilidad contractual a cargo de la Entidad Delegante, pues lo contrario sería desnaturalizar la protección que brinda la estabilidad jurídica.

75. C. Pizarro Wilson, "Obligaciones y responsabilidad civil”, Revista Chilena de Derecho Privado, No. 13,2009 , p. 242. 


\section{LA ARBITRABILIDAD DEL INCUMPLIMIENTO DEL ESTADO A LA CLÁUSULA DE ESTABILIDAD}

En esta sección se estudiará cómo la Ley APP regula el arbitraje [4.1]. Posteriormente se tratará si el incumplimiento del Estado a la cláusula de estabilidad es un caso de arbitrabilidad de actos administrativos [4.2], para, finalmente concluir que el incumplimiento a la cláusula de estabilidad es arbitrable [4.3].

\subsection{El arbitraje al amparo de la Ley APP}

El artículo 20.2 de la Ley APP prescribe la posibilidad de incluir una cláusula arbitral en el contrato de gestión delegada, por lo que no queda duda que existe habilitación legal para acudir a sede arbitral y resolver las controversias que surjan de estos contratos. Sin embargo, existen una serie de exigencias para que pueda llevarse a cabo este proceso.

El artículo en mención exige que antes de someter la controversia a cualquier método heterocompositivo, las partes realicen diálogos directos o mediación. Si no fuere posible solucionar la disputa, entonces la ley prescribe que el inversionista deberá agotar la vía administrativa antes de llevar el conflicto a arbitraje. El artículo 20 del Reglamento a la Ley APP establece que "[p]revio a iniciar el arbitraje, el gestor privado tendrá la obligación de agotar internamente la vía administrativa ante la propia entidad pública delegante [...] (énfasis añadido)" ${ }^{\prime 76}$.

En caso que no sea la Entidad Delegante quien altere la estabilidad jurídica, podría presentarse un problema, puesto que el Reglamento a la Ley APP exige que la vía administrativa se agote ante la propia entidad delegante y no queda claro qué sucede en aquellos casos en los que el acto de aplicación no fue emitido por dicha entidad. 
Si es necesario que antes de acudir a arbitraje se agote la vía administrativa ante la propia entidad delegante, pero dicha entidad no emitió el acto que alteró la estabilidad jurídica, ¿qué debe hacer el inversionista? A fin de evitar que en sede arbitral la Entidad Delegante objete la competencia del tribunal bajo el argumento de que no se cumplieron todos los presupuestos de admisibilidad, es importante analizar los distintos escenarios.

Por un lado podría pensarse que sin el agotamiento de la vía administrativa no es posible iniciar el proceso arbitral. De ser así, sin importar quién emitió el acto será necesario agotar la vía administrativa ante la entidad delegante. Afirmar aquello implicaría que se requiere de acto administrativo de dicha entidad a fin de poder agotar la vía administrativa y en consecuencia accionar la sede arbitral. A continuación, se partirá de esta premisa a fin de analizar sus efectos.

Como se señaló en la sección 3.4.2 en los casos en los que es otra entidad del Estado la que rompe la estabilidad jurídica, el retomar el equilibrio económico del contrato se presenta como una alternativa plausible para destruir los efectos del hecho dañoso. Ante ello pueden presentarse tres escenarios: (i) La entidad delegante retoma el equilibrio económico del contrato. En este caso, tal como se expuso en la sección 3.4.2 existe una situación que puede asimilarse a la destrucción del hecho prohibido. Así, al no existir controversia, no es necesario el agotamiento de la vía administrativa, razón por la cual este escenario no amerita mayor análisis; (ii) La entidad delegante no retoma el equilibrio económico del contrato y dicha negativa se declara a través de un acto administrativo. En este caso, entonces este es el acto que podría impugnarse a fin de agotar la vía administrativa; (iii) La entidad delegante no retoma el equilibrio económico del contrato, pero dicha negativa no se declara a través de un acto administrativo. Este es el caso que genera mayor dificultad. Por un lado, esta omisión no puede ser entendida como un hecho administrativo, pues el COA, en su artículo 127, es claro al definirlo como "toda actividad material", sin dejar paso a que las omisiones de la Administración constituyan hechos. Por este motivo no es posible activar la vía administrativa a través de los me- 
dios existentes para la impugnación de un hecho. Por otro lado, tampoco cabría el silencio positivo ya que los temas contractuales no son objeto de silencio administrativo ${ }^{77}$. Ello se debe a la naturaleza y objetivo del reclamo realizado por el inversionista. El retomar el equilibrio económico del Contrato exige un proceso de negociación entre las partes, por lo que no es posible que el contenido de un contrato sea modificado mediante silencio administrativo. Resulta indispensable que medie consentimiento y el silencio no puede constituir la aceptación de la Entidad Delegante para la renegociación del contrato. En consecuencia, en este escenario no existe acto administrativo que puede ser objeto de impugnación. Siendo así ¿cómo puede el inversionista agotar la vía administrativa conforme lo exige la Ley APP y su Reglamento?

Este trabajo sostiene que la respuesta a esta pregunta se halla en una interpretación del artículo 20 del Reglamento a la Ley APP. Esta disposición es clara al señalar que la vía administrativa debe agotarse ante la misma entidad delegante. Siendo así, debe entenderse que este requisito únicamente cabe en aquellos casos en los que el hecho violatorio del contrato (i) fue emitido por la entidad delegante; (ii) por su naturaleza está sujeto a una impugnación administrativa ante esta entidad; y, (iii) el remedio que ofrece la vía administrativa sea eficaz para recomponer el incumplimiento a la cláusula de estabilidad.

Afirmar lo contrario, pondría al inversionista en una situación de indefensión pues al verse imposibilitado de cumplir los requisitos de admisibilidad, no podría accionar la sede arbitral. Esta situación llevaría al inversionista a una encrucijada en la que se vería obligado a buscar que la entidad delegante emita un acto administrativo a fin de agotar, de manera aparente, la vía administrativa.

Aquello contravendría la finalidad de este requisito y llevaría a la conclusión de que el reconocimiento del arbitraje en la Ley

77. Al respecto la Procuraduría General del Estado señaló que "no se puede considerar al contratista como administrado a fin de beneficiarse del silencio, por cuanto al haberse celebrado un contrato administrativo, las relaciones entre las partes se rigen por lo estipulado en el contrato". Procuraduría General del Estado, Oficio No. 13521, RO No. 233, 12/07/2010. 
APP es una mera ficción, ya que el agotamiento de la vía administrativa resultaría sumamente gravoso para el inversionista a tal punto que la cláusula arbitral devendría en inejecutable. En consecuencia, la posición de este trabajo es que no corresponde agotar la vía administrativa cuando no sea posible interponer recurso de impugnación alguno ante la propia Entidad Delegante.

Por otro lado, si bien la ley reconoce la posibilidad de arbitraje nacional e internacional, también impone una serie de exigencias para que el arbitraje se lleve a cabo. En primer lugar, tal como lo prescribe el artículo19 del Reglamento a la Ley APP, tanto para arbitraje nacional como internacional, la cláusula arbitral deberá ser aprobada por el Procurador General del Estado. Respecto al arbitraje nacional, el artículo 21 del Reglamento señala que (i) el proceso debe ser administrado en un centro de arbitraje de reconocida trayectoria, que no tenga menos de 10 años de experiencia; (ii) el arbitraje debe ser en Derecho; (iii) la legislación aplicable debe ser ecuatoriana; y, (iv) los laudos deben ser definitivos y obligatorios para las partes.

En cuanto al arbitraje internacional, este último podrá ventilarse únicamente en una sede regional, tal como lo exige el artículo 19 de la Ley $\mathrm{APP}^{78}$. Además, conforme lo prescribe el artículo 22 del Reglamento, este arbitraje (i) será en derecho; (ii) en idioma castellano; y, (iii) la legislación aplicable será la ecuatoriana.

Finalmente, este artículo prescribe que "todas las controversias relacionadas, directa o indirectamente, con asuntos de naturaleza tributaria no podrán ser resueltas mediante arbitraje y deberán tramitarse ante los tribunales competentes de la República del Ecuador"79. El alcance de esta disposición debe ser analizado junto con el segundo inciso del artículo 20.2 de la Ley APP según el cual "[n]o se someterán a arbitraje los asuntos tributarios, así como ningún otro acto que se derive directamente de la potestad legislativa y regulatoria del Estado ecuatoriano" ${ }^{\prime 80}$. Al

78. Es artículo prescribe que "[e]n el caso de que se sometan las controversias contractuales al arbitraje internacional, este se realizará ante una instancia arbitral regional latinoamericana".

79. Ley APP, N. 1, Art. 19.

80. Ley APP, N. 1, Art. 20. 
comparar ambas disposiciones es posible evidenciar que la prohibición respecto a temas tributarios es más amplia que aquella respecto a la potestad legislativa y regulatoria del Estado. Sin embargo, como se evidenciará en este artículo, ninguna de estas prohibiciones impide que se someta a arbitraje el incumplimiento del Estado a la Cláusula de Estabilidad.

\subsection{El incumplimiento del Estado a la cláusula de estabili- dad: ¿un caso de arbitrabilidad de actos administrativos?}

Como se señaló en la sección 3.3, el incumplimiento del Estado a la cláusula de estabilidad se materializa a través de actos administrativos. Sin perjuicio de las distintas posturas que existen respecto a la posibilidad de someter a arbitraje estos actos ${ }^{81}$, e independientemente de que este artículo se incline a favor de su arbitrabilidad, a continuación se aclararán ciertas salvedades sobre el caso particular del incumplimiento a la cláusula de estabilidad, a fin de analizar si este incumplimiento es un caso de arbitrabilidad de actos administrativos.

En primer lugar, debe recordarse que en el caso que nos ocupa existe un acto administrativo que genera daños sin ser necesariamente anulable. Ello se debe a que, como se señaló anteriormente, el acto con el cual se irrumpe la estabilidad jurídica no tiene por qué incurrir en alguna de las causales de nulidad contempladas en el artículo 105 del $\mathrm{COA}^{82}$. En este sentido, no cabe discutir en ninguna sede su ilegitimidad, es decir que condenar al Estado al pago de la indemnización no implica cuestionar en sede arbitral la legalidad del acto administrativo en cuestión. El inversionista no pretende anular el acto, sino que espera simplemente que la Entidad Delegante lo indemnice por el daño ocasio-

81. Es posible identificar tres tendencias: (i) aquella que niega por completo la arbitrabilidad de los actos administrativos; (ii) aquella que admite la arbitrabilidad de los efectos económicos de los actos administrativos, negando la posibilidad de arbitrar aspectos relacionados a su legalidad; y, (iii) aquella que acepta que se arbitre inclusive la legalidad de los actos administrativos, con los únicos límites impuestos en la ley. Véase, J. P. Aguilar, Arbitrabilidad de Actos Administrativos, Tesis de Postgrado. Universidad San Francisco de Quito, 2014 y F. LARrEA, "Arbitrabilidad de los Actos Administrativos Contractuales", Revista Ecuatoriana de Arbitraje, No, 7, 2015.

82. Véase, N. 68. 
nado, por lo que somete a arbitraje un asunto netamente contractual: la responsabilidad indemnizatoria que recae en el Estado en razón de su incumplimiento.

En segundo lugar, cabe señalar que la posibilidad de arbitrar actos administrativos está condicionada a que estos estén vinculados a la relación contractual, es decir, que sean actos administrativos contractuales y no actos de ius imperi. Por lo general, la aplicación de las modificaciones a la normativa estabilizada será un acto que se realiza en atención a las potestades soberanas del Estado y no es un acto realizado por el Estado en su calidad de parte contractual. De hecho, como se anticipó en este artículo, es del todo posible que el acto que altera la estabilidad jurídica, no sea emitido por la Entidad Delegante. Es por ello que en estos casos, no corresponde analizar si es posible arbitrar el acto administrativo, pues la respuesta será negativa, ya que el acto emitido por una entidad distinta a la Entidad Delegante no es, de forma alguna, un acto administrativo contractual.

Sin perjuicio de ello, no se debe dejar de lado la posibilidad de que el acto a través del cual se altera la estabilidad jurídica, sea a su vez un acto de ejecución contractual. Por ejemplo, en un caso en el cual la normativa que fue estabilizada incluya normas que regulen la forma de terminar unilateralmente el contrato. Si esas normas son modificadas y, posteriormente, la Entidad Delegante aplica dichas modificaciones al inversionista; el acto de terminación unilateral sería a su vez un acto de ejecución contractual y un acto que altera la normativa estabilizada.

En situaciones como esta cabría, entonces, analizar si el acto administrativo contractual puede ser arbitrable. Al respecto, este artículo se inclina por aceptar arbitrar la legalidad de este acto de ejecución contractual. De hecho, cabe resaltar, que a través de una interpretación de la propia Ley APP, es posible sostener que la legalidad de actos administrativos, en el marco de una disputa suscitada en un contrato de gestión delegada, es arbitrable. El artículo 20 la referida norma prescribe que: 
[...] Le corresponde a la jurisdicción contencioso-administrativa la resolución de las controversias que se susciten respecto de contratos de gestión delegada:

a. Cuando no se haya pactado arbitraje nacional o internacional regional en el contrato de gestión delegada.

b. En los casos que corresponda, si transcurrido el plazo previsto para la notificación al interesado con la resolución que agota la vía administrativa, no se ha ejercido la acción ante la jurisdicción arbitral pactada en el correspondiente contrato de gestión delegada ${ }^{83}$.

Este artículo es claro al señalar que existen únicamente dos escenarios en los que las controversias derivadas del contrato de gestión delegada deberán ser resueltas ante la jurisdicción contencioso administrativa: (i) ante la inexistencia de cláusula arbitral y (ii) ante la falta de ejercicio de acción en sede arbitral dentro del plazo de 30 días, previsto en el artículo 20 del Reglamento a la Ley APP 84 .

Por lo tanto, no existe razón para considerar que exista competencia exclusiva de la jurisdicción contencioso administrativa para pronunciarse sobre la legalidad de los actos administrativos que afecten al contrato de gestión delegada. Si así lo habría querido el legislador bastaba que incluya un tercer caso (iii) en el que señale que "le corresponde a la jurisdicción contencioso-administrativa la resolución de las controversias que se susciten respecto de contratos de gestión delegada: [...] c. Cuando esté en discusión la legalidad de cualquier acto administrativo". Al no haberse incluido una exclusión en esos términos, y tomando en cuenta que en Derecho Público la arbitrabilidad debe medirse en función al principio de legalidad y no a la transigibilidad ${ }^{85}$; no existe

83. Ley APP, N. 1, Art. 20.

84. El artículo 20 del Reglamento a la Ley APP prescribe que “[...] Una vez agotada la vía administrativa, el gestor privado tendrá 30 días hábiles para demandar por la vía arbitral”.

85. En arbitraje en el sector público es inadecuado limitar la arbitrabilidad a la transigibilidad de la disputa. Al contrario, dado que la Administración actúa con base en el principio de legalidad, el establecer si procede o no pactar arbitraje dependerá de si la ley lo permite y en qué términos lo hace. Véase, J. P. Aguilar, N. 81; F. LarreA, N. 81; J. P. Aguilar, "Derecho administrativo y transigibilidad", Revista Ecuatoriana de Arbitraje, No. 6, 2014; R. HuAPAYA TAPIA, "Diez Tesis sobre las Asociaciones PúblicoPrivadas (APP) en nuestro régimen legal”, Círculo de Derecho Administrativo, No. 13, 2013, p. 31; E. JEQUIER LEHUEDÉ, "La arbitrabilidad de la controversia contencioso-administrativa en el ámbito de las relaciones contractuales del Estado", Revista Chilena de Derecho, Vol. 40 (1), 2013, p. 179; F. VICENT 
impedimento para que un tribunal arbitral conozca asuntos relacionados a la legalidad de actos administrativos que alteren el contrato de gestión delegada; ello con la salvedad de los asuntos tributarios y los actos derivados de la potestad legislativa o regulatoria, dado que en este caso sí existe prohibición expresa.

A pesar de este argumento, es importante dejar en claro al lector que, por regla general, en casos de incumplimiento del Estado a la cláusula de estabilidad no corresponderá analizar la viabilidad de someter el acto administrativo a arbitraje. Las situaciones en las que se abrirá paso a este análisis son reducidas, pues, como se explicó anteriormente, exigen que el acto a través del cual se altere la estabilidad jurídica sea a su vez un acto administrativo contractual, cuya legitimidad esté en discusión.

\subsection{El incumplimiento a la cláusula de estabilidad es arbitrable}

En este apartado se evidenciará que el incumplimiento a la cláusula de estabilidad no es un acto que derive de la potestad legislativa ni regulatoria del Estado, por lo que su arbitrabilidad no se encuentra prohibida [4.3.1]. Como consecuencia de ello, el reclamo que presenta el inversionista ante el incumplimiento del Estado a la cláusula de estabilidad es un asunto netamente contractual [4.3.2].

\subsubsection{El incumplimiento a la cláusula de estabilidad no deriva de la potestad legislativa ni regulatoria del Estado}

El artículo 20.2 de la Ley APP impide que se someta a arbitraje todo "acto que se derive directamente de la potestad legislativa y regulatoria del Estado ecuatoriano" ${ }^{\prime \prime 6}$. A fin de determinar

Chuliá, "Arbitraje de Impugnación de Acuerdos Sociales. Acto Final", Anuario Justicia Alternativa, No. 1, 2001, p. 114; R. CAIVANO, "Planteos de Inconstitucionalidad en el Arbitraje", Revista Peruana de Arbitraje, No. 2, 2006, p. 129; S. MonTES, "La solución de controversias contractuales por la vía arbitral”, Revista de Derecho Público, 2002, p. 142.

86. Ley APP, N. 1, Art. 20. 
si el incumplimiento a la cláusula de estabilidad es arbitrable es fundamental analizar cuáles son los actos directamente derivados de estas dos potestades.

Refiriéndose a los actos que pueden derivar de la potestad legislativa, GoRDILLO aclara que "el régimen jurídico previsto para la función legislativa se aplica únicamente a los actos que sean materialmente legislativos y que además hayan sido realizados por el órgano legislativo (cursivas en el original)"187. Además, señala la diferencia existente entre la ley y los reglamentos; $y$, sobre la base de esta diferenciación, establece que:

[...] Esta notoria diferencia de régimen jurídico entre la ley y el reglamento nos demuestra que el concepto jurídico, formal, de función legislativa, no puede comprender a los reglamentos, a pesar de que por su contenido sean similares. Los órganos administrativos, pues, no ejercen función legislativa (énfasis añadido) ${ }^{88}$.

En efecto, se evidencia que la Ley APP, al excluir la posibilidad de arbitrar actos derivados de la potestad legislativa, se refiere exclusivamente a los actos normativos emitidos por los órganos legislativos o cuasi-legislativos, no los actos administrativos dictados por autoridades públicas. Dichos actos están contenidos en el artículo 120 de la Constitución y ninguno de ellos se refiere a la aplicación de la norma. Así, dado que el incumplimiento del Estado a la cláusula de estabilidad se da mediante la aplicación de la ley, y no por su promulgación [sección 3.2], dicho incumplimiento no deriva de la potestad legislativa del Estado.

Respecto a la potestad reguladora, IBÁÑEZ afirma que:

La potestad reguladora es aquella atribuida por la Constitución Política a diferentes autoridades para que mediante actos administrativos normativos, de carácter general, impersonal y abstracto, sea con sujeción a las reglas generales que señale el le-

87. A. GORDillo, Tratado de Derecho Administrativo, Tomo 8, Fundación de Derecho Administrativo, 2013, p. 91.

88. Ídem, p. 92. 
gislador o con sujeción directamente a lo que determine la misma Constitución Política, se cree por primera vez el ordenamiento jurídico en aquellas materias en las cuales el constituyente considera que debiendo existir regulación ella no deba ser de carácter legislativo (énfasis añadido) ${ }^{89}$.

En consecuencia, el ejercicio de esta potestad se manifiesta a través de actos de carácter general. En cambio, el incumplimiento del Estado a la cláusula de estabilidad se materializa necesariamente a través de un acto de carácter individual, pues requiere la aplicación, al inversionista, de la modificación a la normativa estabilizada (sección 3.3).

Si bien la Constitución no se refiere expresamente a la potestad regulatoria, es posible definir su alcance al amparo del artículo 10 (h) del Estatuto del Régimen Jurídico Administrativo de la Función Ejecutiva (en adelante, ERJAFE). Este artículo prescribe que la potestad de regulación "[e]s la facultad de emitir normas para el adecuado y oportuno desarrollo y cumplimiento de la política pública y la prestación de los servicios, con el fin de dirigir, orientar o modificar la conducta de los agentes regulados (énfasis añadido)" ${ }^{\prime \prime 0}$. Por su parte, la Corte Suprema de Justicia, se refirió a esta potestad en sentencia de 9 de enero de 2004 al establecer que:

La Constitución en el inciso segundo del art. 228 dice que la facultad legislativa de los consejos provinciales y de las municipalidades se expresará en ordenanzas. La expresión "facultad legislativa" se presta a equívocos; habría sido preferible la facultad "normativa" o "reguladora" que es indiscutiblemente lo que el legislador constituyente quiso expresar, puesto que él bien sabía que "legislar" en el sentido estricto de dictar leyes, es potestad exclusiva de la Función Legislativa; en todo caso, la disposición en referencia muestra que es absolutamente constitucional la atribución de las municipalidades y

89. J. E. IBÁÑ̃z NAJAR, “Alcance y Límites de las Potestades Reguladora y Reglamentaria. La división de competencias existente entre la ley y el acto administrativo normativo, sea regulador o reglamentario", Revista Vniversitas, 2013, p. 26.

90. Estatuto del Régimen Jurídico Administrativo de la Función Ejecutiva. Artículo 10, RO No. 536, $18 / 03 / 2002$. 
los consejos provinciales de expedir normas secundarías, a través de ordenanzas. En consecuencia, la facultad de las municipalidades para sancionar mediante multas las infracciones tipificadas en las ordenanzas y más normas que rigen la actividad municipal, se halla establecida en las disposiciones constitucionales relativas al Régimen Seccional (énfasis aña(ido $)^{91}$.

En este caso, la Corte Suprema estableció que la potestad reguladora es aquella que permite expedir normas secundarias, es decir, la facultad de emitir actos normativos. Sin embargo, también sostuvo que es a través de esta facultad que las municipalidades están en capacidad de "sancionar mediante multas las infracciones tipificadas en las ordenanzas y más normas que rigen la actividad municipal"; por lo que podría también pensarse que en este caso la Corte Suprema consideró que la facultad reguladora abarca la potestad de aplicar dichas normas secundarias.

No obstante, un análisis más amplio de la jurisprudencia ecuatoriana permite concluir que en realidad la potestad regulatoria se refiere a la facultad de emitir normas. Así, por ejemplo, la sala de lo Contencioso Administrativo de la Corte Suprema de Justicia, en sentencia de 13 de diciembre de 2008, tras analizar las disposiciones de las letras a y b del artículo 51 de la Ley para la Reforma de las Finanzas Públicas, concluyó que estas “determinan una potestad regulatoria en materia de remuneraciones en el sector público" ${ }^{\prime \prime 2}$. Las disposiciones en cuestión se refieren a la potestad de (a) "determinar las políticas salariales a aplicarse en las instituciones del Estado" y (b) "establecer mediante resoluciones de carácter obligatorio para todas las instituciones del Estado, las normas relativas al control de la masa salarial y la regulación de su incremento". Por lo tanto, es claro que la potestad regulatoria se asimila a la facultad de emitir normas de carácter general.

Asimismo, el Tribunal Constitucional, en sentencia de 21 de enero de 2003 identificó que una de las facultades regulatorias

91. Corte Suprema de Justicia, Sala de lo Contencioso Administrativo, Juicio No. 220/2001, 09/01/2004. 92. Corte Suprema de Justicia, Sala de lo Contencioso Administrativo, Juicio No. 391-06, 13/12/2006. 
del CONATEL consiste en la posibilidad de "que expida el reglamento que se aplicará para otorgar las concesiones de los servicios de telecomunicación" ${ }^{\prime \prime 9}$. De igual forma, en sentencia de 06 de abril de 2016, la Corte Constitucional señaló que "el entonces Consejo Nacional de Radiodifusión y Televisión tenía en general una facultad regulatoria de los servicios de radiodifusión y televisión y específicamente, una potestad normativa para expedir reglamentos administrativos o técnicos complementarios en esta materia (énfasis añadido)"94.

Sobre la base de ello, se concluye que la potestad regulatoria implica la facultad de emitir normas de carácter general. Al no ser posible arbitrar actos con efecto erga omnes (pues solo se admite la arbitrabilidad de actos administrativos contractuales ${ }^{95}$ ), no sorprende entonces que la Ley APP excluya la posibilidad de arbitrar los actos derivados directamente de la potestad legislativa o regulatoria del Estado, pues en ambos casos estamos ante actos de carácter general.

\subsubsection{El incumplimiento del Estado a la Cláusula de Estabili- dad es un asunto netamente contractual, razón por la cual su arbitrabilidad es indiscutible}

A lo largo de este artículo ha quedado claro que al suscribir una cláusula de estabilidad el Estado asume una obligación de no hacer y que en caso de no ser posible destruir los efectos dañosos del hecho prohibido, la Entidad Delegante está obligada a indemnizar al inversionista. Así, el inversionista acude a arbitraje con el objetivo de que el tribunal arbitral condene a la Entidad Delegante al pago de la indemnización correspondiente. Conocer sobre esta indemnización es un asunto netamente contractual.

El tribunal arbitral deberá analizar si existió o no incumplimiento y sobre la base de ello resolver respecto de la responsabilidad contractual que recae en la Entidad Delegante. En ningún

\footnotetext{
93. Tribunal Constitucional, Caso No. 009-2002-TC, 21/01/2003.

94. Corte Constitucional, Caso No. 006-10-IA, 06/04/2016.

95. Véase, J. P. Aguilar, N. 81 y F. Larrea, N. 81.
} 
momento el tribunal arbitral se verá en la necesidad de pronunciarse sobre la validez de las leyes promulgadas o sobre la potestad soberana que tiene el Estado para aplicar dichas leyes. Siendo así, no existe un sometimiento a arbitraje de actos que deriven de la potestad legislativa o regulatoria del Estado.

Lo mismo sucede con la prohibición que contempla el artículo 20.2 respecto a la posibilidad de arbitrar los asuntos tributarios. Es decir, en un caso en el que la normativa estabilizada contemple normas que otorgan incentivos tributarios, no se pretende que el tribunal arbitral conozca los temas tributarios, sino únicamente que se pronuncie sobre el incumplimiento contractual y sus efectos indemnizatorios.

En consecuencia, no queda duda que el incumplimiento del Estado a la Cláusula de Estabilidad es un asunto contractual y, como tal, es arbitrable al amparo de lo prescrito en el artículo 20.2 de la Ley APP.

\section{Conclusiones}

A lo largo de este artículo ha sido posible llegar a una serie de conclusiones que permiten evidenciar que el incumplimiento del Estado a la Cláusula de Estabilidad es arbitrable. Estas conclusiones se refieren (i) al régimen de la cláusula de estabilidad en el Derecho de Inversiones y su regulación en la legislación ecuatoriana; (ii) a la naturaleza de los compromisos asumidos por el Estado a través de la suscripción de una cláusula de estabilidad jurídica y los efectos de su incumplimiento; y, (iii) a la arbitrabilidad del incumplimiento del Estado a la cláusula de estabilidad.

Sobre el régimen de la cláusula de estabilidad en el Derecho de Inversiones y su regulación en la legislación ecuatoriana:

Primero, en el Derecho de Inversiones la cláusula de congelamiento tiene por objetivo otorgar al inversionista seguridad sobre el régimen jurídico que regulará su inversión. 
Segundo, la suscripción de una cláusula de estabilidad no contraviene la soberanía estatal. El Estado no está impedido de emitir nuevas normas, o de modificarlas, sino que, en ejercicio de sus facultades soberanas, asume el compromiso de no aplicar determinadas normas al inversionista.

Tercero, en Ecuador, la Ley APP prescribe, como uno de sus incentivos, la posibilidad de incluir una cláusula de congelamiento parcial. Así, no es posible otorgar estabilidad sobre todo el ordenamiento jurídico, sino que exclusivamente sobre la normativa sectorial específica que haya sido declarada como esencial en el contrato de gestión delegada. Además, no tiene cabida el cuestionar la validez de estas cláusulas por considerarlas contrarias a la soberanía estatal pues el artículo 10 del Reglamento a la Ley APP prescribe claramente que pese a la incorporación de una cláusula de estabilidad, el Estado conserva su facultad regulatoria.

Sobre la naturaleza de los compromisos asumidos por el Estado a través de la suscripción de una cláusula de estabilidad jurídica y los efectos de su incumplimiento

Primero, a través de la cláusula de estabilidad el Estado contrae una obligación de no hacer, cuya prestación consiste en abstenerse de aplicar al inversionista las modificaciones a las normas sobre las cuáles se pactó estabilidad.

Segundo, sobre la base de aquello se evidencia que el incumplimiento del Estado consiste en aplicar al inversionista alguna modificación a la normativa estabilizada, por lo que la simple promulgación o modificación de una ley no implica incumplimiento.

Tercero, este incumplimiento se da mediante un acto administrativo, a través del cual se crea una nueva situación jurídica para el inversionista en cuestión, el cual, previo a dicho acto, no se encontraba bajo los efectos de la norma que fue modificada. 
Cuarto, debido a que toda obligación nace para cumplirse, ante el incumplimiento de una obligación de no hacer, debe preferirse la destrucción del hecho prohibido por sobre la indemnización de perjuicios. Así, solo en caso de no ser posible tal destrucción cabrá la indemnización. Frente al incumplimiento a la Cláusula de Estabilidad, la forma en la que se alcanza esta destrucción dependerá de quien alteró la estabilidad jurídica: (i) la Entidad Delegante u (ii) otra entidad del Estado. En el primer escenario la destrucción del hecho prohibido requiere que se deje sin efecto el acto por medio del cual se aplicó cualquier modificación a la normativa estabilizada (lo cual incluye revertir cualquier daño generado). En cambio, en el segundo caso, la destrucción, por equivalencia, consiste en retomar el equilibrio económico del Contrato. Por último, en caso de no ser posible la destrucción del hecho, es la Entidad Delegante quien debe indemnizar al inversionista los perjuicios generados, independientemente de si fue ella quien modificó la estabilidad jurídica.

\section{Sobre la posibilidad de someter a arbitraje el incumplimiento del Estado a la Cláusula de Estabilidad:}

Primero, la Ley APP impone una serie de requisitos para que se lleve a cabo el arbitraje, entre los cuales se encuentran (i) requisitos de admisibilidad: agotamiento de fases previas: diálogos directos, mediación y vía administrativa; (ii) requisitos de validez: la necesidad de contar con aprobación del Procurador General del Estado; (iii) requisitos sobre el proceso: la necesidad de ser un arbitraje en derecho, el idioma, la normativa aplicable, el centro ante el que puede llevarse, etc.; y, (iv) requisitos sobre la arbitrabilidad: una prohibición amplia respecto a los asuntos tributarios y una más restringida sobre actos que deriven directamente de las potestades legislativa y regulatoria.

Segundo, el incumplimiento del Estado a la Cláusula de Estabilidad no es, por regla general, un caso en el que quepa analizar la arbitrabilidad de actos administrativos. Sin embargo, en los casos, excepcionales, en los que sí corresponde; este trabajo se inclina por la posibilidad de arbitrar dichos actos, ello tomando en 
consideración las particularidades que existe en el Derecho Público respecto a la transigibilidad y la arbitrabilidad.

Tercero, el acto mediante el cual se materializa el incumplimiento del Estado no deriva directamente de la potestad legislativa ni regulatoria del Estado, pues de estas potestades derivan exclusivamente actos de carácter normativo, no de carácter individual. Por lo tanto, el incumplimiento del Estado a la cláusula de estabilidad es un asunto netamente contractual que, al no derivar de ninguna de estas potestades, es plenamente arbitrable al amparo de lo prescrito en el artículo 20.2 de la Ley APP.

Sobre la base de estas conclusiones, se confirma que el incumplimiento del Estado a la Cláusula de Estabilidad es arbitrable, pues no se encuentra contenido en la prohibición del artículo 20.2 de la Ley APP. Ello en razón que, al suscribir una cláusula de estabilidad, el Estado asume una obligación de no hacer, cuyo incumplimiento acarrea una responsabilidad indemnizatoria a cargo de la Entidad Delegante. El acto mediante el cual se configura este incumplimiento no deriva de la potestad legislativa o regulatoria del Estado, y en consecuencia, no existe razón para cuestionar su arbitrabilidad al amparo del artículo 20.2 de la Ley APP. 